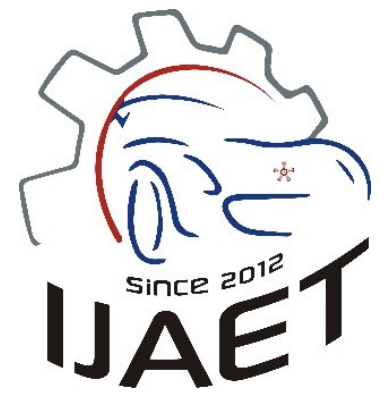

e-ISSN: 2146 - 9067

International Journal of Automotive

Engineering and Technologies

journal homepage:

https://dergipark.org.tr/en/pub/ijaet

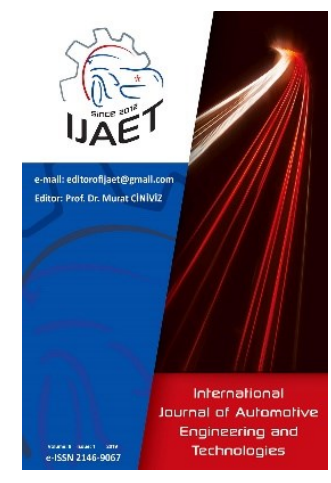

Original Research Article

\title{
Reducing emissions of an SI engine by alternative spark plugs with hydrogen addition and variable compression ratio
}

\author{
Oğuz Baş ${ }^{1 *}$, Mustafa Atakan Akar², Hasan Serin ${ }^{3}$ \\ $1,{ }^{*}$ Amasya University, Technology Faculty, Mechanical Engineering, Amasya, Turkey \\ ${ }^{2,3}$ Cukurova University, The Faculty Of Engineerıng, Automotive Engineering, Adana, Turkey
}

\section{ARTICLE INFO}

${ }^{1} 0000-0003-2301-2306$

${ }^{2}$ 0000-0002-0192-0605

${ }^{3} 0000-0003-2679-3099$

* Corresponding author oguz.bas@amasya.edu.tr

Received: Mar 20, 2019

Accepted: May 03, 2020

Published by Editorial Board Members of IJAET

(C) This article is distributed by Turk Journal Park System under the CC 4.0 terms and conditions.

\begin{abstract}
As a consequence of the emissions-cheating scandals and more strict emission regulations enforce researchers to reduce emissions out and find alternative fuels for SI engines. For this purpose, various spark plugs are available in the market with different electrode materials. However, they have not been tested together with different engine parameters. Hence, emissions out from a variable compression spark-ignited engine with different spark plugs and hydrogen enrichment were the scope of this study. The tests were conducted with a fourstroke, single-cylinder, naturally aspirated, variable compression ratio (VCR) engine. Two different compression ratios (CR) of 8.5:1 and 10:1 at maximum brake torque (MBT) spark timing applied to assess the effects of different spark plugs and hydrogen usage at different engine loads. Copper, iridium and platinum spark plugs were tested for each experiment condition. Also, hydrogen was added through the intake manifold with flow rates of 0,2 and $41 / \mathrm{min}$ to enhance the combustion of the VCR engine. Carbon monoxide $(\mathrm{CO})$, carbon dioxide $\left(\mathrm{CO}_{2}\right)$, nitrogen oxides $\left(\mathrm{NO}_{\mathrm{x}}\right)$ and unburned hydrocarbons (UHC) emission values were measured in this study. According to test results, with iridium and platinum spark plug usage, hydrogen addition and higher $\mathrm{CR}$, the engine emitted lower $\mathrm{CO}$ and UHC at all engine loads. However, a higher amount of $\mathrm{CO}_{2}$ was emitted because of increased completeness of the combustion and the amount of $\mathrm{NO}_{\mathrm{x}}$ emissions rose due to increment in-cylinder temperatures. These variances were more apparent with platinum spark plug usage compared to the iridium spark plug. As a result, the usage of iridium and platinum spark plugs were shown lower incomplete emissions products out, except $\mathrm{NO}_{\mathrm{x}}$ emissions.
\end{abstract}

\section{Introduction}

Fossil fuels such as petroleum, coal and natural gas are the main energy sources of today's world. Day by day, growing energy demand and environmental issues have been getting more critical. Naturally, the automotive industry is severely challenging to high fuel costs and strict emission regulations due to the abovementioned issues $[1,2]$.

As known, people and goods transportation are provided by the utilization of fossil fuels such as gasoline, diesel, compressed natural gas, liquefied petroleum gas, etc. Despite diesel 
market share is still very high among them in European Union nations, in mid-term, it is expected that the diesel engine inevitably will lose its share in the market rapidly [3, 4]. Especially, considering recent emission cheating scandals, the development of the SI engine is being more and more critical for the future of the automotive industry. From this point, it can be interpreted that the gasoline engine must be improved and the usage of alternative fuels has to be evaluated with caution from different aspects [5, 6].

As known, SI engines have high power to weight ratio, stable and silent performance. Besides an SI engine has relatively low prices and requires less maintenance [7, 8]. Furthermore, they are more feasible for fuel alternating such as CNG and LPG compared with a diesel engine which has a similar volume $[9,10]$. Yet, thermal efficiency and torque output of SI engines are relatively lower comparing with modern compression ignited engines [11]. These drawbacks have been posed an obstacle to the widespread utilization of SI engines such as heavy-duty types of machinery [12 - 14].

A lean-burn operation is just one of the most effective ways to solve the problems mentioned above [15]. However, lean-burn is limited due to ignition-related problems such as the slow flame initiation and propagation along with potential misfiring [16]. In the future of sparkignited engine, it is expected that gasoline engines will operate with much higher compression ratios and much leaner fuel-to-air ratios for the sake of combustion enhancement and fuel economy $[17,18]$. Furthermore, these will deteriorate the electrode degradation and erosion of the spark plugs more [19 - 21]. To overcome these challenges, usage of durable alternative spark plugs is seemed urgent for spark-ignited engines.

The purpose of a spark plug (SP) is to ensure controlled combustion of the fuel in the engine. By doing so, a high voltage generated by the ignition coil is introduced into the combustion chamber and the compressed fuel/air mixture is then ignited by the electric spark passing between the electrodes. Charge volume and density of the spark plug in the combustion chamber are other serious factors that influence engine performance and emission characteristics. By increasing combustion volume, charge density or elongating ignition time, combustion completeness can be enhanced [22]. However, there are some objections to improve them. For instance, to increase the charge density ignition system requires higher secondary coil voltage to initiate combustion [23]. Thus, producing the required voltage with these conditions would cause more spark electrode erosion and shorter service lifetime of the spark plug [17, 20, 22].

To improve SPs, suppliers have presented different types of spark plugs with various electrode materials to the market such as yttrium, iridium, platinum, etc. The main purposes of usage of these noble metal materials are rapid attainment of operating temperature, increasing cold starting reliability, enhancing ignition, smooth engine operation and reducing wear rate of the electrode [24]. In this context, these types of spark plugs that are available in the market must be assessed from different aspects such as performance characteristics, emission values, electrode erosions and carbon buildup, etc.

Usage of hydrogen which is one of the most prominent alternative fuels brings a lot of advantages for SI engines due to its some superior properties. Hydrogen is a colorless, inodorous and zero-carbon emitted fuel when fired with oxygen $[14,15,25,26]$. The chemical reaction of two hydrogen atoms and an oxygen atom generates energy outputs and the product is water only. Characteristic features of hydrogen such as flammability limits, low ignition energy, high burning rate ensure more stable combustion process and engine operation even for ultra-clean air-fuel mixtures. So, hydrogen enables to increase the combustion limits [27]. Hydrogen has a wider flammability range in the air that allows the engine to operate with either rich or lean mixtures. Thus, by leaning the air-fuel mixture better fuel economy can be obtained due to increased combustion completeness of the fuel [28]. In addition to that, lean combustion results in lower $\mathrm{NO}_{\mathrm{x}}$ emission depending on lower combustion temperature. More complete combustion ensured by hydrogen enrichment leads to a reduction of the emission products [29, 30]. Zero carbon structure of the hydrogen combustion decreases $\mathrm{CO}, \mathrm{CO}_{2}$ and $\mathrm{HC}$ emissions. On the contrary, 
hydrogen existence in combustion rises the cylinder temperature with stoichiometric conditions, thus $\mathrm{NO}_{\mathrm{x}}$ emission increases. However, $\mathrm{NO}_{\mathrm{x}}$ emission rise can be compensated by the lean operation owing to diminished combustion temperature [10, 25].

On the other hand, compression ratio (CR) is one of the key facts that influence engine performance, emissions out and design. Engine efficiency can be improved further with a higher $\mathrm{CR}$ that enables increment in the expansion ratio providing effective utilization of the fuel [31 34]. Moreover, it yields decreased exhaust gas dilution of a fresh mixture which increases cylinder temperature and pressure. This allows shorter ignition delay and combustion duration as a consequence of increased flame speed. Also, CR increment is a functional way to attain a wider backfire-free running range of the engine. Besides, increasing $\mathrm{CR}$ minimizes residual gas amount in the combustion chamber and thereby reduces the possibility of backfire [35].

From those points of views, although there are studies on spark plug locations [22, 36 - 38], spark plug gap, electrode geometry [39], dual spark plug [40], multiple sparks [23], increased spark discharge energy [12, 41], erosion and failure characteristics $[18,19,21]$ in literature, however, usage of alternative spark plugs with different electrode materials and their effect on emission characteristics have not been investigated in detail. In this study, the effect of different spark plug types on emissions characteristics of a spark-ignition engine fuelled with hydrogen-enriched gasoline at various engine loads and CRs were studied. Brake specific emission values of carbon monoxide (CO), carbon dioxide $\left(\mathrm{CO}_{2}\right)$, nitrogen oxides $\left(\mathrm{NO}_{\mathrm{x}}\right)$ and un-burnt hydrocarbon (UHC) emissions were determined to evaluate test parameters.

\section{Experimental Methodology}

\subsection{Materials}

\subsection{Test Engine}

Engine tests were performed on a four-stroke, single-cylinder, naturally aspirated, watercooled, variable compression engine that can run with both gasoline and diesel fuel by replacing the engine head. "Enginesoft" software was utilized for experimental data logging. This software logs for 60 seconds when logging starts and at the end of this period gives the average values of experimental data. Technical specifications of the engine and schematic representation test rig were given in Table 1 and Figure 1, respectively.

Table 1. Technical specifications of the engine

\begin{tabular}{ll}
\hline Descriptions & Specifications \\
\hline Brand - Model & Kirloskar Oil Engines-240 \\
Configuration & Single Cylinder \\
Type & Four Stroke, \\
Cooling & Water Cooling \\
Displacement & $661 \mathrm{cc}$ \\
Bore & $87.5 \mathrm{~mm}$ \\
Stroke & $110 \mathrm{~mm}$ \\
Power & $4.5 \mathrm{Kw}$ 1 1800 rpm \\
CR range & $6: 1-10: 1$ \\
Injection Variation & $0-25^{\circ} \mathrm{BTDC}$ \\
Peak Pressure & $77.5 \mathrm{~kg} / \mathrm{cm}^{2}$ \\
Weight & $160 \mathrm{~kg}$ \\
Lubricating System & Forced Feed System \\
\hline
\end{tabular}

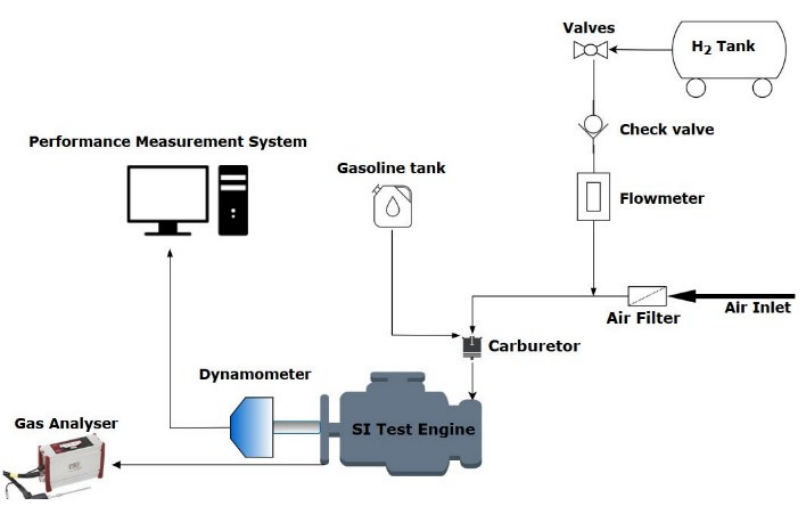

Figure 1. Schematic representation hydrogen-enriched test engine rig

Table 2. Technical specifications of the dynamometer

\begin{tabular}{ll}
\hline Descriptions & Specifications \\
\hline Model & AG10 \\
Make & $\begin{array}{l}\text { Saj Test Plant Pvt. Ltd. } \\
\text { Cardan shaft model 1260 } \\
\text { End flanges both side }\end{array}$ \\
$\begin{array}{l}\text { type A } \\
1.6 \mathrm{bar}\end{array}$ \\
Water inlet & 60 \\
Hot coil voltage max & \\
Continuous current & 5.0 \\
amps & $3.5 \mathrm{~kg}$ \\
Load & $130 \mathrm{~kg}$ \\
Weight & $10000 \mathrm{rpm}$ \\
Speed max. &
\end{tabular}

In these experiments, an eddy current dynamometer was used for the determination of power output and a Sa-Beam load cell for setting the torque. The AG series bi-directional eddy current dynamometers can measure engines up to $400 \mathrm{~kW}$ and it can be adopted with various control systems. Dynamometer load is measured by strain gauge load cell and the engine speed is 
Table 5. Technical specifications of spark plugs used in experiments

\begin{tabular}{|c|l|l|l|l|}
\hline \multirow{5}{*}{} & Type & Copper & Iridium & Platinum \\
\cline { 2 - 5 } & Band & BOSCH & NGK & NGK \\
\cline { 2 - 5 } & Parts No. & UR3DC & CR9EIX & CR9EHVX-9 \\
\cline { 2 - 5 } & Thread Size & $10 \mathrm{~mm}$ & $10 \mathrm{~mm}$ & $10 \mathrm{~mm}$ \\
\cline { 2 - 5 } & Thread Pitch & $1.0 \mathrm{~mm}$ & $1.0 \mathrm{~mm}$ & $1.0 \mathrm{~mm}$ \\
\cline { 2 - 5 } & Seat Type & Gasket & Gasket & Gasket \\
\cline { 2 - 5 } & Resistor & Yes & Yes & Yes \\
\cline { 2 - 5 } & Resistor Value & $5 \mathrm{~K} \mathrm{Ohm}$ & $5 \mathrm{~K} \mathrm{Ohm}$ & $5 \mathrm{~K}$ Ohm \\
\cline { 2 - 5 } & Reach & $19 \mathrm{~mm}$ & $19 \mathrm{~mm}$ & $19 \mathrm{~mm}$ \\
\cline { 2 - 5 } & Hex Size & $16 \mathrm{~mm}$ & $16 \mathrm{~mm}$ & $16 \mathrm{~mm}$ \\
\cline { 2 - 5 } & Terminal Type & Threaded Stud & Threaded Stud & Threaded Stud \\
\cline { 2 - 5 } & Overall Height & ISO & ISO & Bantam \\
\cline { 2 - 5 } & Original SPG & $0.7 \mathrm{~mm}$ & $0.8 \mathrm{~mm}$ & $0.7 \mathrm{~mm}$ \\
\cline { 2 - 5 } & Heat Range & 8 & 8 & 8 \\
\cline { 2 - 5 } ELECTRODE & Longevity & $30 \mathrm{k}$ & $40-50 \mathrm{k}$ & $50 \mathrm{k}$ \\
\cline { 2 - 5 } & Material & Copper & Iridium & Platinum \\
\cline { 2 - 5 } & Type & Fine wire & Fine wire & Fine wire \\
\cline { 2 - 5 } & Size & $2.5 \mathrm{~mm}$ & $0.6 \mathrm{~mm}$ & $0.6 \mathrm{~mm}$ \\
\hline \multirow{2}{*}{ GROUND } & Material & Copper & Nickel & Platinum \\
\cline { 2 - 5 } & Type & Standard & Standard & Standard \\
\hline \multirow{2}{*}{ ELECTRODE } & & \\
\hline
\end{tabular}

determined by shaft mounted 360 PPR rotary encoder. The technical specifications of the dynamometer and load cell are given in Table 2 and Table 3.

Table 3. Technical specifications of the load cell

\begin{tabular}{ll}
\hline Descriptions & Specifications \\
\hline Model & 60001 \\
Type & S Beam Universal \\
Capacity & $0-50 \mathrm{~kg}$ \\
Non-linearity & $<+/-0.025 \%$ \\
Non-repeatability & $<+/-0.010 \%$ \\
Operating temperature range & $-20{ }^{0} \mathrm{C}$ to $+70^{\circ} \mathrm{C}$ \\
Combined Error & $<+/-0.025 \%$ \\
\hline
\end{tabular}

\subsubsection{Emission measurement device}

MRU Air Delta $1600 \mathrm{~V}$ mobile exhaust gas analyzer was utilized to measure exhaust emissions. With the help of analyzer software, necessary emission data was collected. Accuracy of the gas analyzer is $\pm 10 \mathrm{ppm}$ for $\mathrm{CO}$, $1 \%$ for $\mathrm{CO}_{2}$ and $\pm 1 \mathrm{ppm}$ for $\mathrm{NO}_{\mathrm{x}}$. In Table 4, measurement ranges, accuracy and resolution values of the emission device were shown.

Table 4. Measurement ranges, accuracy and resolution of the emission device

\begin{tabular}{ll}
\hline Descriptions & Specifications \\
\hline $\mathrm{CO}$ & $0-10 \%$ \\
$\mathrm{CO}_{2}$ & $0-20 \%$ \\
$\mathrm{HC}$ & $0-20000 \mathrm{ppm}$ \\
$\mathrm{NO}$ & $0-4000 \mathrm{ppm}$ \\
$\mathrm{NO}_{2}$ & $0-1000 \mathrm{ppm}$ \\
Accuracy & According to OIML-class 1 \\
Ambient Temperature & $+5^{\circ}-+45^{\circ} \mathrm{C}$ \\
Exhaust Gas Temperature & $\mathrm{Max} 650^{\circ} \mathrm{C}$ \\
\hline
\end{tabular}

\subsubsection{Spark Plugs}

In this study, three different spark plugs that are available commercially were used to evaluate their effects on the emission characteristics of the test engine. Technical specifications of copper (conventional), iridium and platinum spark plugs used in these experiments were given in Table 5.

\subsection{Experimental Procedure}

Throughout the engine experiments, $\mathrm{H}_{2}$ with $99.99 \%$ purity was added through the intake manifold of the engine to reduce emissions out from the test engine. Emission measurement experiments were executed with two different CRs (8.5:1 and 10:1) at MBT. During the experiments, engine loads of $8 \mathrm{Nm}, 13 \mathrm{Nm}$ and $17 \mathrm{Nm}$ were implemented to evaluate the effects of different spark plugs and hydrogen usage on emissions under different engine loads. Copper, iridium and platinum spark plugs were adopted with same spark plug gap size for each experiment condition. Besides, hydrogen was induced through the intake manifold with flow rates of $01 / \mathrm{min}(\mathrm{H} 0), 21 / \mathrm{min}(\mathrm{H} 2)$ and $41 / \mathrm{min}$ (H4) to enhance the combustion of VCR engine. Before experimental measurements, the engine was run for 5 minutes to attain stable operation conditions. Once the engine had warmed up, all experiments were performed approximately at $90 \mathrm{C}^{\circ}$. As a result, brake-specific emissions of; carbon monoxide $(\mathrm{CO})$, carbon dioxide $\left(\mathrm{CO}_{2}\right)$, nitrogen oxides $\left(\mathrm{NO}_{\mathrm{x}}\right)$ and total unburned 
hydrocarbon (UHC) were obtained to evaluate effects of applied methods on emission characteristics of the test engine.

\section{Results and Discussion}

In this study, each case was tested 5 times to validate the results. The results are given below are arithmetic means of these experiments. The uncertainty of $\mathrm{CO}, \mathrm{CO}_{2}, \mathrm{NO}_{\mathrm{x}}$, UHC emissions and brake power measurements were approximately $\pm 2.5 \%, \pm 2 \%, \pm 3 \%, \pm 4 \%$ and $\pm 5 \%$, respectively.

\subsection{CO Emissions}

Figures 2-7 illustrate the brake specific CO emission results of the experiments. The formation of $\mathrm{CO}$ emission is directly related to the combustion completeness of the fuels and the insufficient amount of oxygen [32].

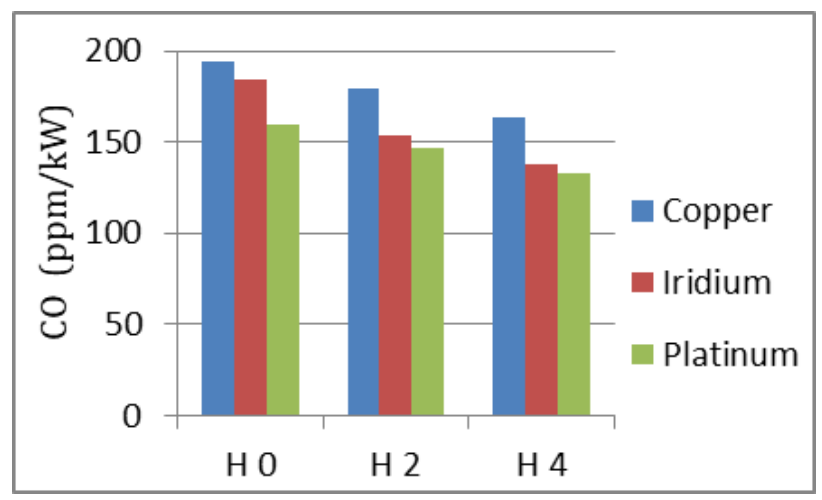

Figure 2 Brake specific $\mathrm{CO}$ emission values for engine load of $8 \mathrm{Nm}$ and $\mathrm{CR}$ of $8.5: 1$

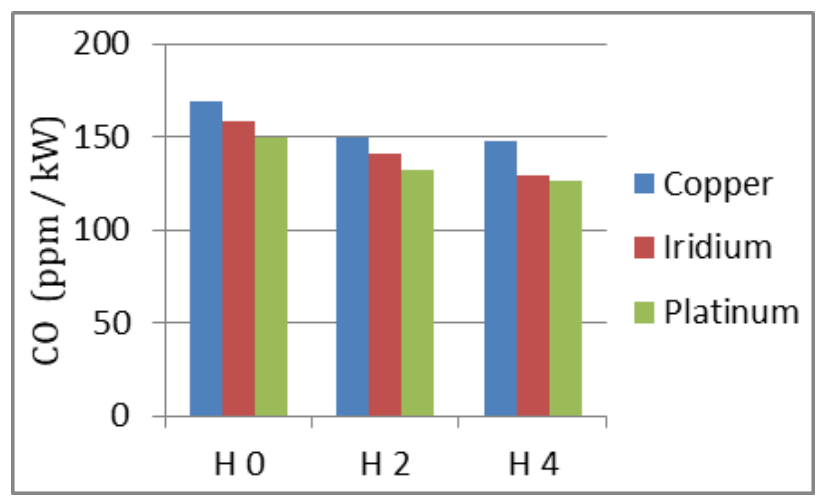

Figure 3 Brake specific $\mathrm{CO}$ emission values for engine load of $13 \mathrm{Nm}$ and $\mathrm{CR}$ of $8.5: 1$

It can be seen from the figures that using iridium and platinum SPs reduced $\mathrm{CO}$ emissions remarkably at all engine loads. Probably, the higher charge density of these SPs triggered combustion completeness and helped to reduce incomplete combustion products [22, 42]. However, platinum SP reduced $\mathrm{CO}$ toxic emissions more than the iridium spark plug in general. $\mathrm{CO}$ emissions were reduced between $1.01 \%-15.77 \%$ for iridium spark plugs and $7.66 \%-18.32 \%$ for platinum SP.

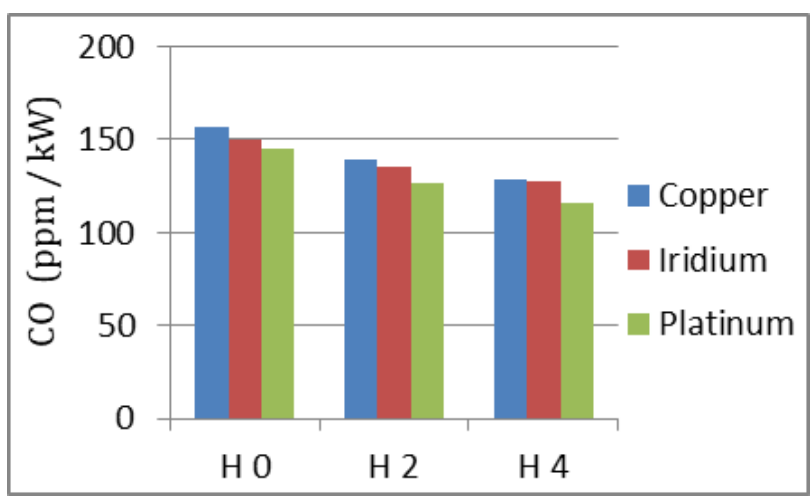

Figure 4 Brake specific $\mathrm{CO}$ emission values for engine load of $17 \mathrm{Nm}$ and $\mathrm{CR}$ of 8.5:1

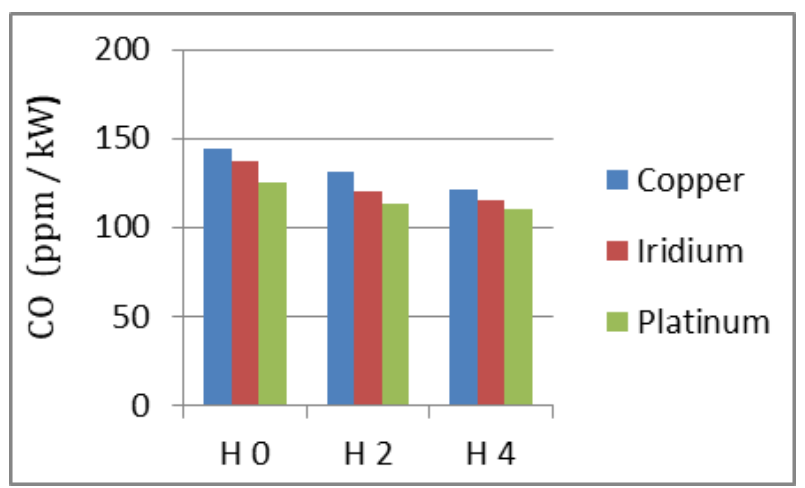

Figure 5 Brake specific $\mathrm{CO}$ emission values for engine load of $8 \mathrm{Nm}$ and CR of 10:1

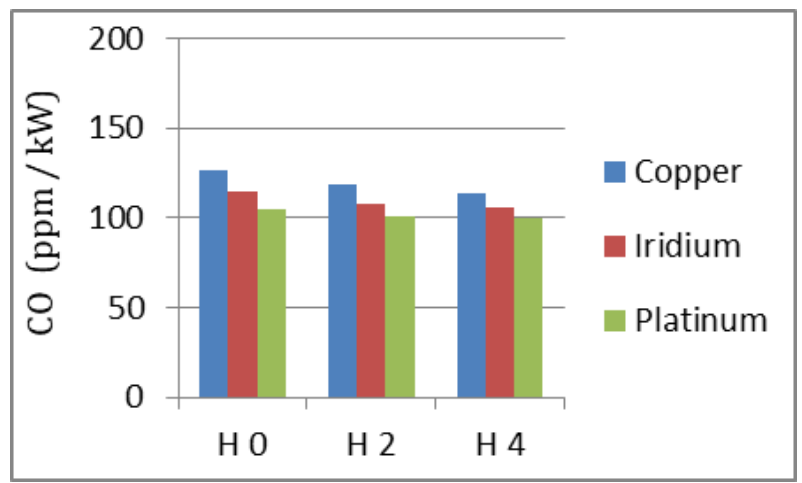

Figure 6 Brake specific $\mathrm{CO}$ emission values for engine load of $13 \mathrm{Nm}$ and CR of 10:1

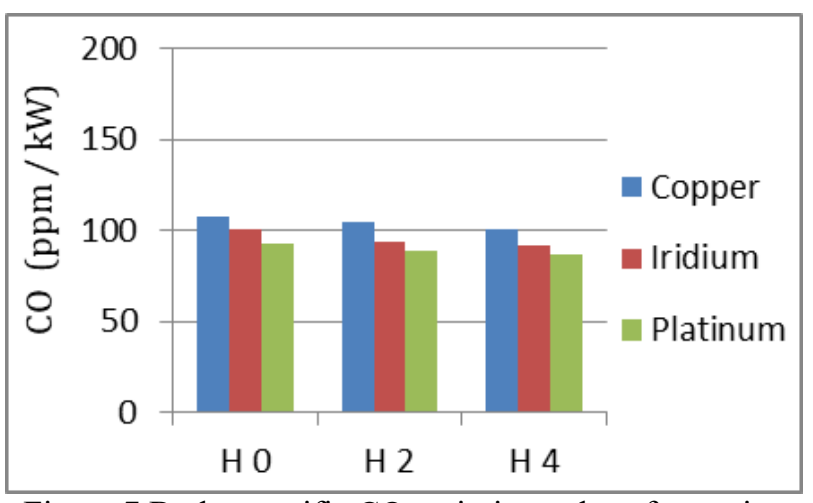

Figure 7 Brake specific $\mathrm{CO}$ emission values for engine load of $17 \mathrm{Nm}$ and CR of 10:1 
Moreover, hydrogen enrichment decreased CO emissions due to its combustion reaction accelerator function and carbonless structure. Induction hydrogen with the flow rate of $21 / \mathrm{min}$ $(\mathrm{H} 2)$ and 4 1/min (H4) reduced $\mathrm{CO}$ emissions by $8.93 \%$ and $13.68 \%$ respectively on average compared to un-hydrogenated operations.

Besides, both higher a compression ratio and higher engine loads resulted in dropping incomplete emission products of $\mathrm{CO}$ at all combinations of hydrogen additions and spark plugs. The lowest $\mathrm{CO}$ emission out was recorded for the platinum spark plug, H4 fuel, 10:1 compression ratio and $17 \mathrm{Nm}$ engine load combination.

\section{2. $\mathrm{CO}_{2}$ Emissions}

As it can be seen from the Figures 8-13, for iridium and platinum SPs, higher $\mathrm{CO}_{2}$ emissions were measured since these SPs improved the combustion and thus $\mathrm{CO}$ and $\mathrm{UHC}$ compositions are converted into $\mathrm{CO}_{2}$ emissions. If they need to be compared, platinum SP increased $\mathrm{CO}_{2}$ emissions more than iridium SP. $\mathrm{CO}_{2}$ emissions were increased between $2.91 \%$ $14.11 \%$ for iridium SPs and 5\% - 25.49\% for platinum SP. Nevertheless, hydrogen addition increased $\mathrm{CO}_{2}$ formation, too. $\mathrm{CO}_{2}$ emissions may have been expected to be lower because of the combustion of zero-carbon fuel, however, more complete combustion and increased UHC conversion into $\mathrm{CO}_{2}$ were measured due to hydrogen's burning speed increasing function.

As a result, the hydrogen addition of $\mathrm{H} 2$ and $\mathrm{H} 4$ increased $\mathrm{CO}_{2}$ emissions by $16.83 \%$ and $45.13 \%$ respectively on average compared to $\mathrm{H} 0$ fuel. On the other hand, increasing compression ratio and engine torque increased $\mathrm{CO}_{2}$ emissions due to more complete combustion.

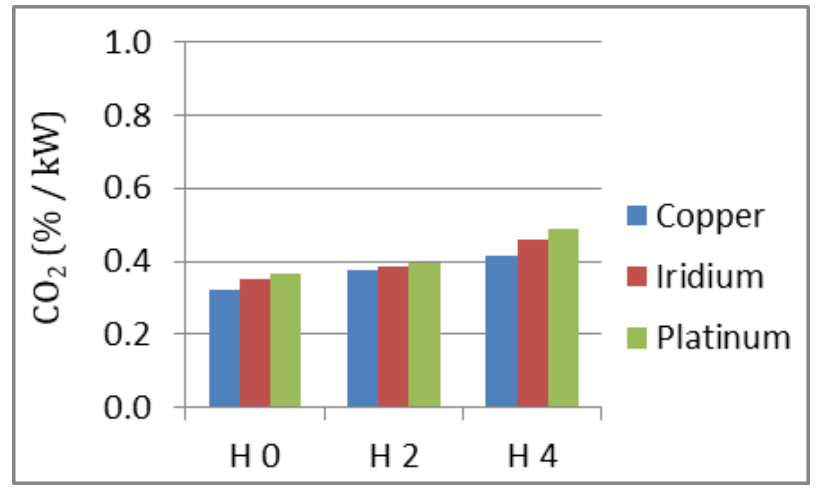

Figure 8 Brake specific $\mathrm{CO}_{2}$ emission values for engine load of $8 \mathrm{Nm}$ and $\mathrm{CR}$ of $8.5: 1$

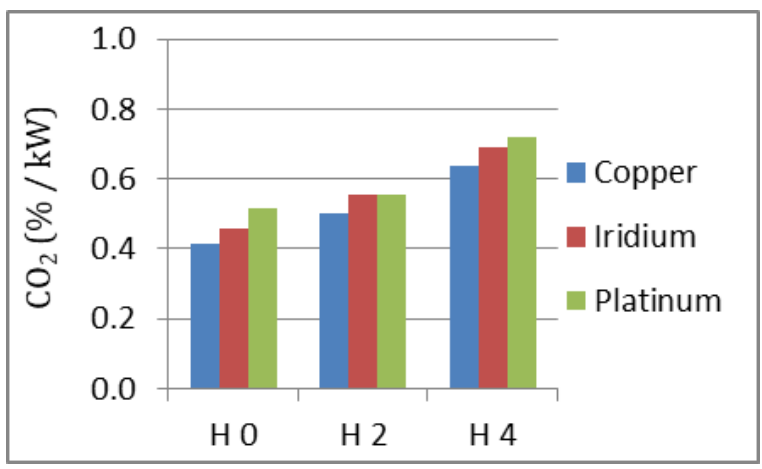

Figure 9 Brake specific $\mathrm{CO}_{2}$ emission values for engine load of $13 \mathrm{Nm}$ and $\mathrm{CR}$ of 8.5:1

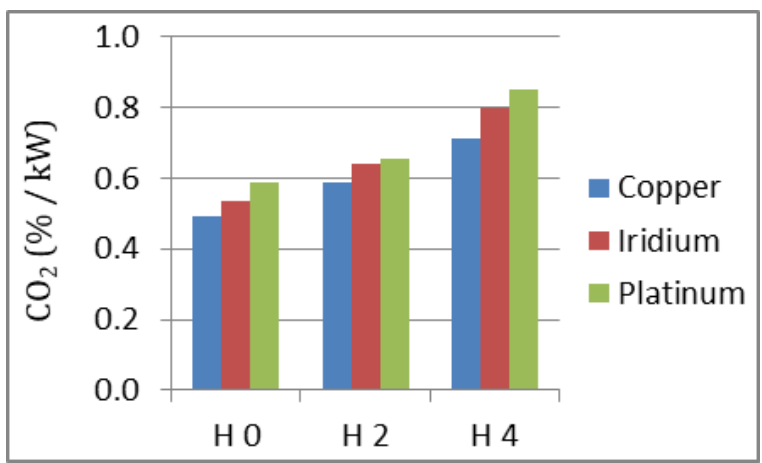

Figure 10 Brake specific $\mathrm{CO}_{2}$ emission values for engine load of $17 \mathrm{Nm}$ and $\mathrm{CR}$ of 8.5:1

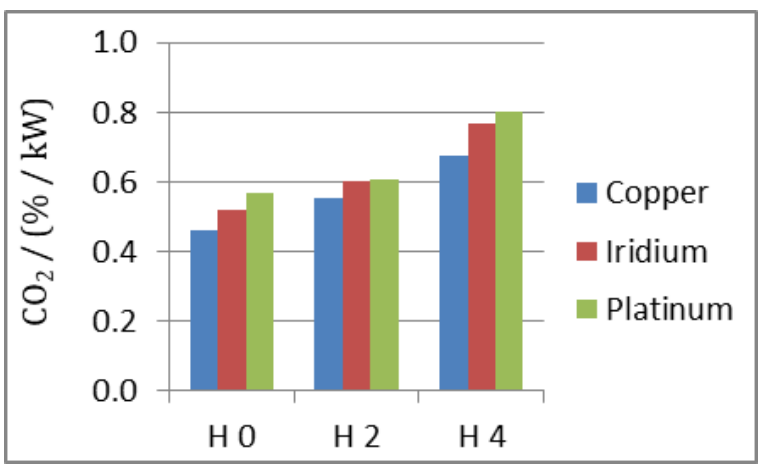

Figure 11 Brake specific $\mathrm{CO}_{2}$ emission values for engine load of $8 \mathrm{Nm}$ and CR of 10:1

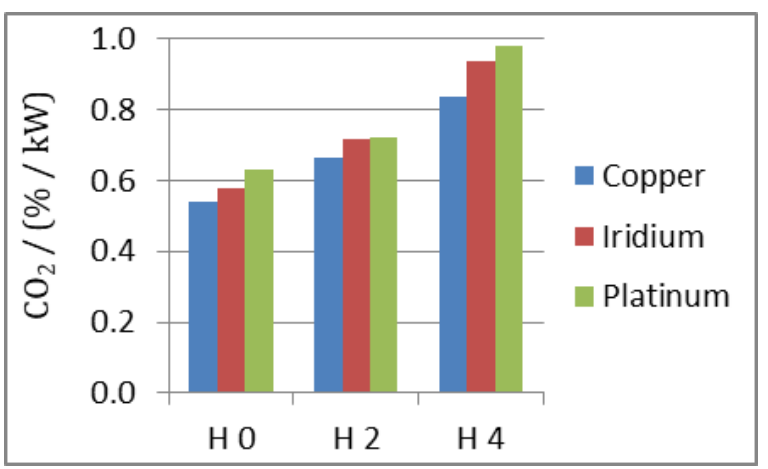

Figure 12 Brake specific $\mathrm{CO}_{2}$ emission values for engine load of $13 \mathrm{Nm}$ and $\mathrm{CR}$ of 10:1

\subsection{NO $\mathrm{N}_{\mathrm{x}}$ Emissions}

$\mathrm{NO}_{\mathrm{x}}$ results of all tests are shown in Figure 1419. $\mathrm{NO}_{\mathrm{x}}$ emissions were increased when the platinum and iridium SPs were used due to the higher temperature accompanied by the increase 
in flame speed and in-cylinder pressure. For platinum SP, the rise in $\mathrm{NO}_{\mathrm{x}}$ became more obvious.

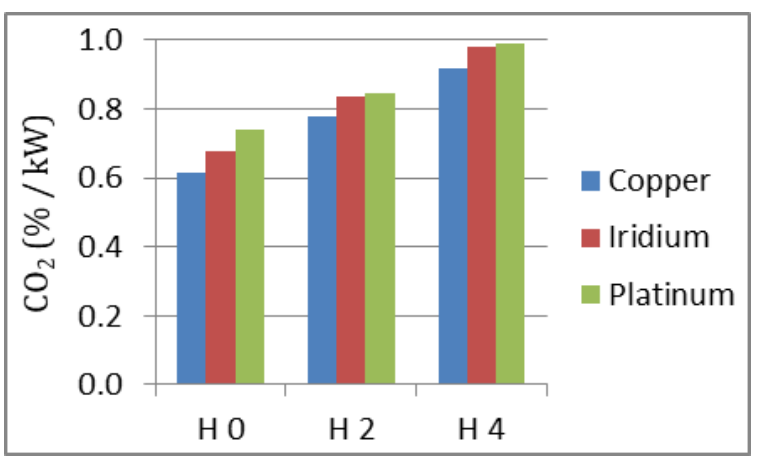

Figure 13 Brake specific $\mathrm{CO}_{2}$ emission values for engine load of $17 \mathrm{Nm}$ and CR of 10:1

Hydrogen enrichment triggered $\mathrm{NO}_{\mathrm{x}}$ formation, too. Higher end-combustion temperature and flame velocity resulted from hydrogen combustion caused a dramatic rise in $\mathrm{NO}_{\mathrm{x}}$ formation [43]. On average, $82.16 \%$ and $204.53 \%$ rise in $\mathrm{NO}_{\mathrm{x}}$ emissions were measured for $\mathrm{H} 2$ and $\mathrm{H} 4$ test conditions, respectively. Moreover, at higher engine loads and higher compression ratios caused $\mathrm{NO}_{\mathrm{x}}$ emissions out increment. For the 10:1 compression ratio, higher $\mathrm{NO}_{\mathrm{x}}$ emissions by between 21-55.2\% were measured comparing with the $8: 1$ case.

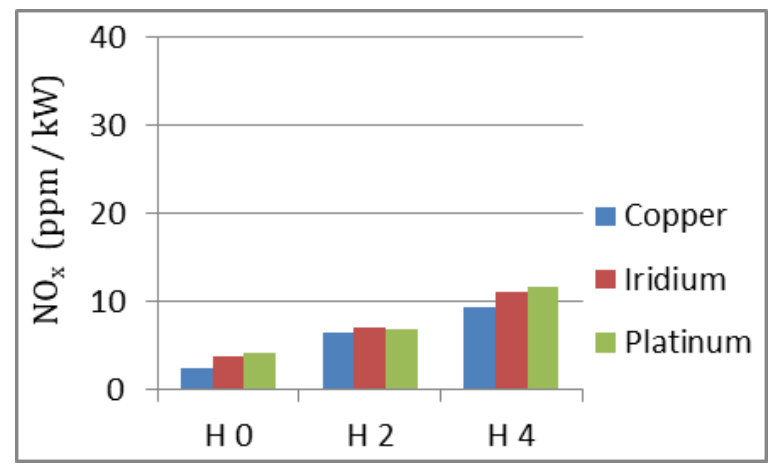

Figure 14 Brake specific $\mathrm{NO}_{\mathrm{x}}$ emission values for engine load of $8 \mathrm{Nm}$ and $\mathrm{CR}$ of $8.5: 1$

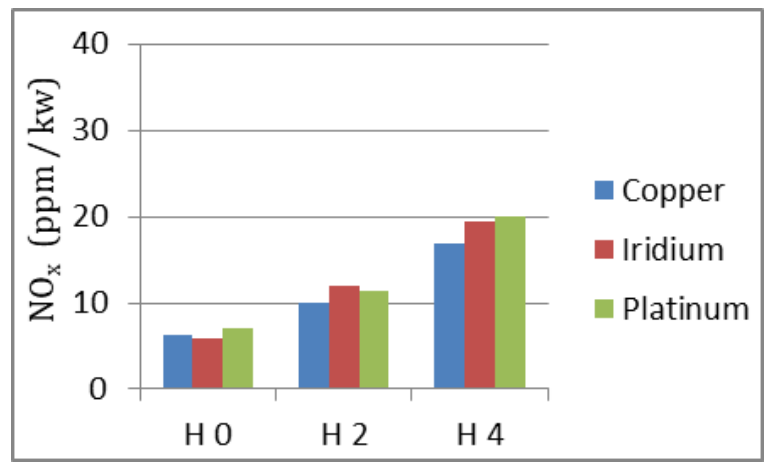

Figure 15 Brake specific $\mathrm{NO}_{\mathrm{x}}$ emission values for engine load of $13 \mathrm{Nm}$ and $\mathrm{CR}$ of 8.5:1

\subsection{UHC Emissions}

It can be seen from Figure 20-25, iridium and platinum SP decreased UHC emission because of improved combustion, remarkably. Platinum SP reduced UHC emissions more than iridium SP. UHC emissions were decreased between $2.51 \%-19.59 \%$ for iridium SPs and $7.62 \%$ $24.12 \%$ for platinum SP.

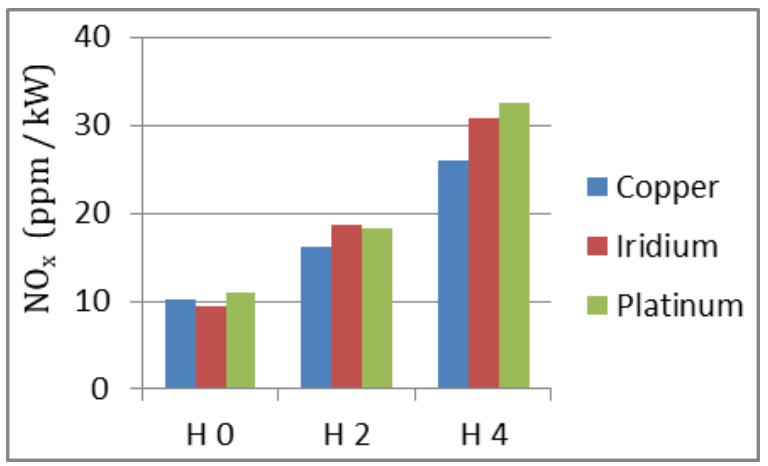

Figure 16 Brake specific $\mathrm{NO}_{\mathrm{x}}$ emission values for engine load of $17 \mathrm{Nm}$ and $\mathrm{CR}$ of 8.5:1

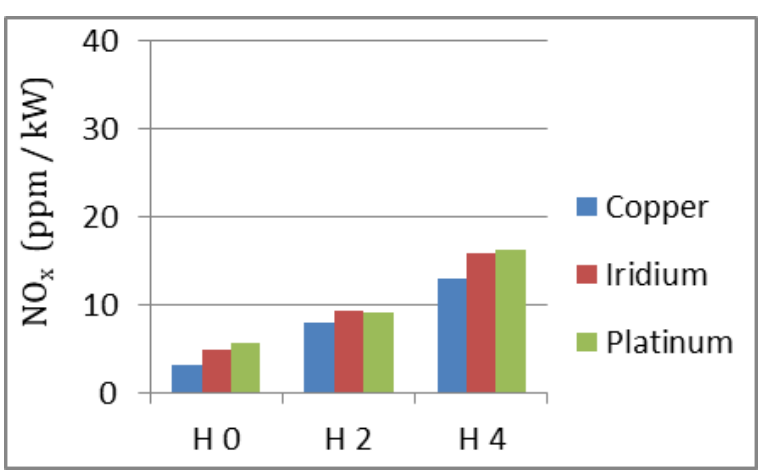

Figure 17 Brake specific $\mathrm{NO}_{\mathrm{x}}$ emission values for engine load of $8 \mathrm{Nm}$ and CR of 10:1

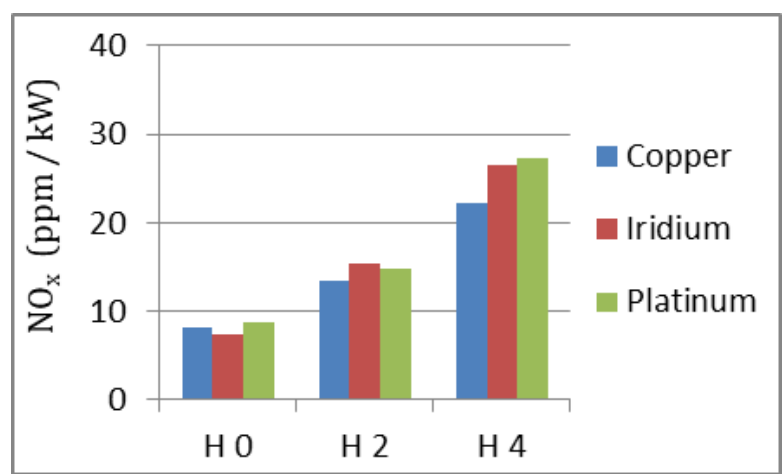

Figure 18 Brake specific $\mathrm{NO}_{\mathrm{x}}$ emission values for engine load of $13 \mathrm{Nm}$ and CR of 10:1

Moreover, UHC emissions were effectively reduced with the increment of the hydrogen flow rate. According to the test results, the brake specific UHC emissions were dropped by $16.62 \%$ and $25.92 \%$ with $\mathrm{H} 2$ and $\mathrm{H} 4$ test fuel, respectively. This result can be attributed to the improvement of the combustion quality through the shorter combustion duration and hydrogen addition that lead to more complete combustion. Additionally, increasing the engine load and compression ratio of the test engine, lower UHC 
was emitted which is an incomplete emission product. The lowest UHC emission out was measured for the platinum spark plug, H4 fuel, 10:1 compression ratio and $17 \mathrm{Nm}$ engine load case.

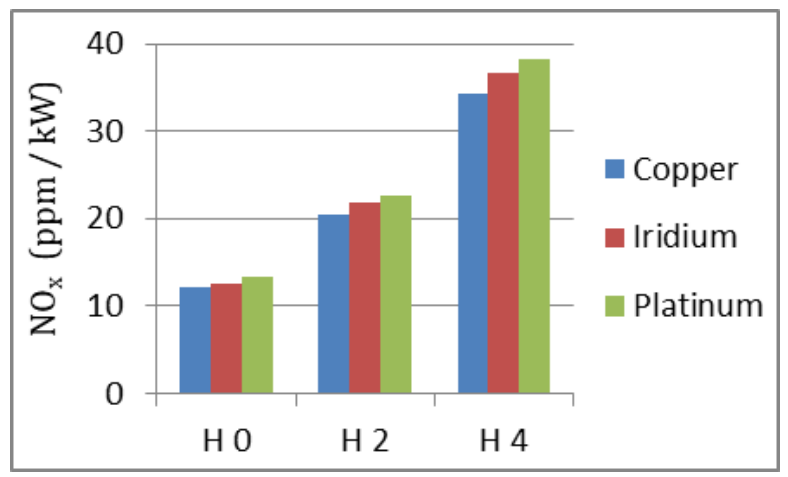

Figure 19 Brake specific $\mathrm{NO}_{\mathrm{x}}$ emission values for engine load of $17 \mathrm{Nm}$ and $\mathrm{CR}$ of 10:1

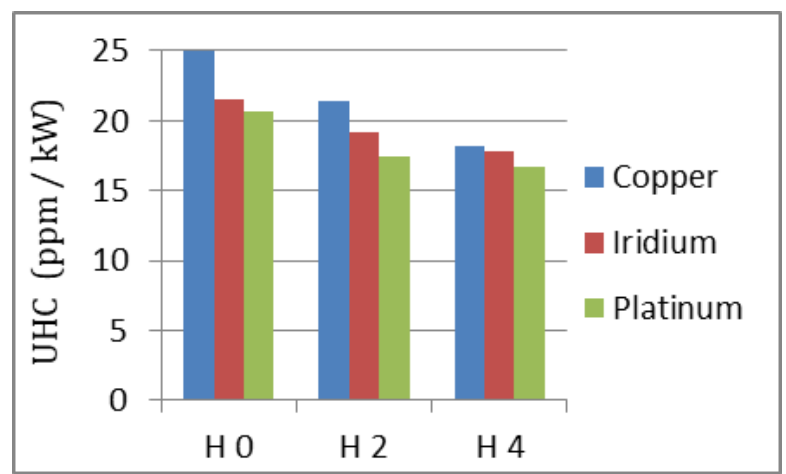

Figure 20 Brake specific UHC emission values for engine load of $8 \mathrm{Nm}$ and $\mathrm{CR}$ of $8.5: 1$

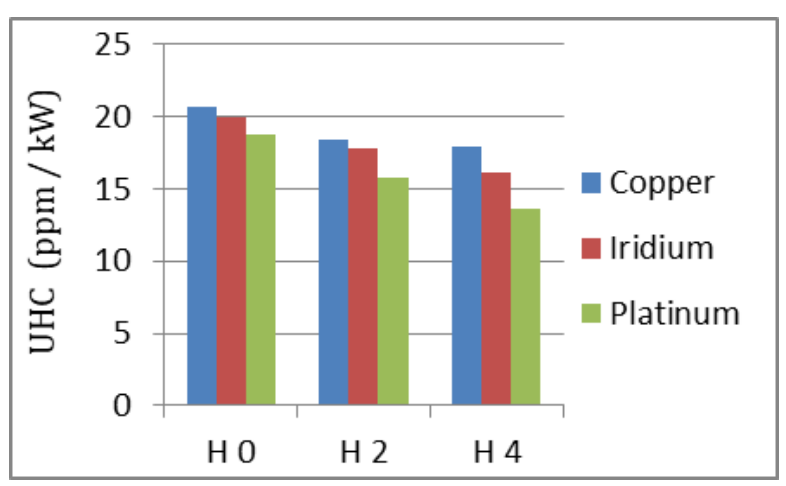

Figure 21 Brake specific UHC emission values for engine load of $13 \mathrm{Nm}$ and $\mathrm{CR}$ of 8.5:1

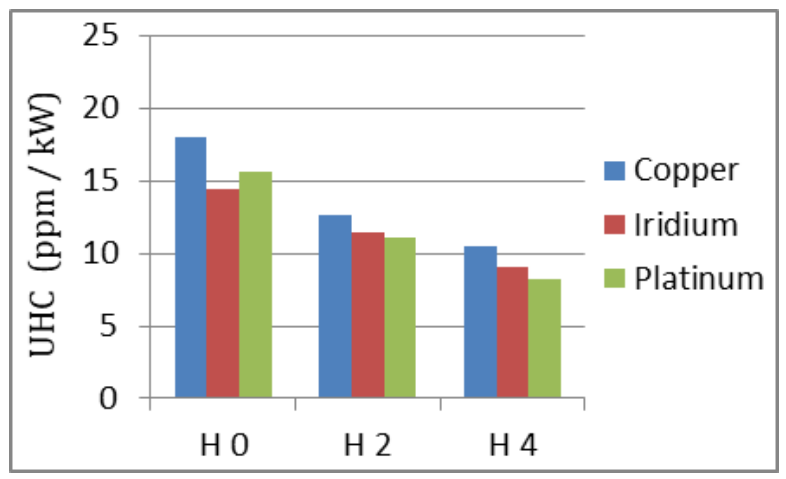

Figure 22 Brake specific UHC emission values for engine load of $17 \mathrm{Nm}$ and $\mathrm{CR}$ of 8.5:1

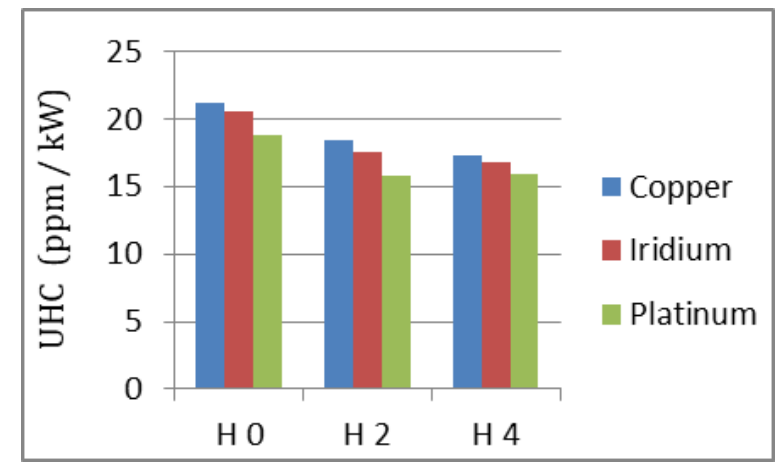

Figure 23 Brake specific UHC emission values for engine load of $8 \mathrm{Nm}$ and $\mathrm{CR}$ of 10:1

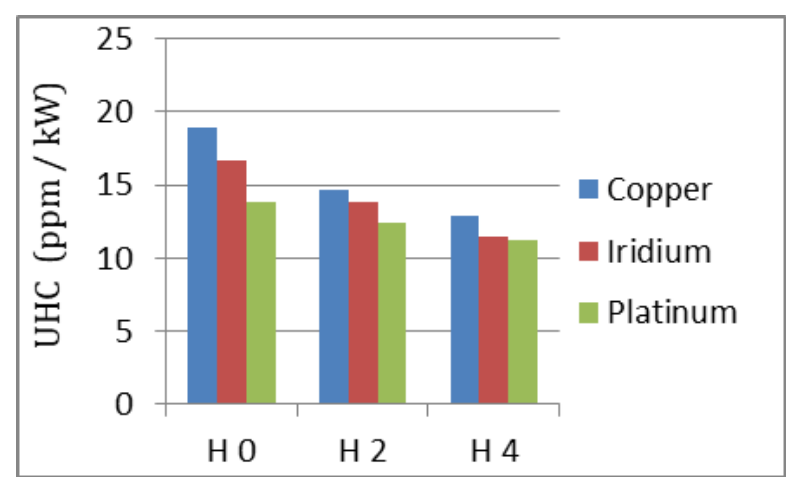

Figure 24 Brake specific UHC emission values for engine load of $13 \mathrm{Nm}$ and $\mathrm{CR}$ of 10:1

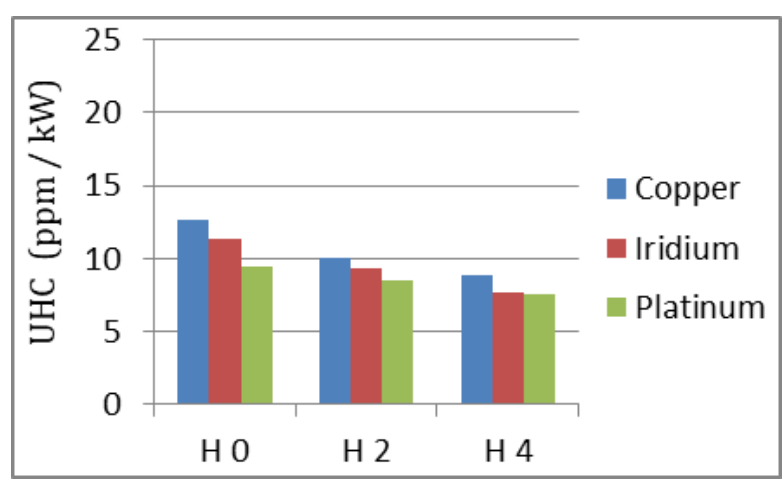

Figure 25 Brake specific UHC emission values for engine load of $17 \mathrm{Nm}$ and $\mathrm{CR}$ of 10:1

\section{Conclusions}

In this study, emission characteristics of an SI engine equipped with different SPs at various CRs, fuelled with pure gasoline and different hydrogen-gasoline bi-fuels were determined. During the experiments the engine CR was set as 8.5:1 and 10:1 and copper, platinum and iridium SPs were performed one by one. Besides, each test condition was executed at different dynamometer loads which are $8 \mathrm{Nm}$, $13 \mathrm{Nm}$ and $17 \mathrm{Nm}$. According to experimental results, the following conclusions can be summarized;

- Changing conventional (copper) spark plug with iridium and platinum spark plugs resulted in lower $\mathrm{CO}$ and $\mathrm{HC}$ and higher $\mathrm{CO}_{2}$ and $\mathrm{NO}_{\mathrm{x}}$ 
emissions at all compression ratios, engine loads and hydrogen flow rates.

- Variations in emission parameters mentioned above were more obvious for platinum spark plug than iridium type.

- Similar to spark plug changing, hydrogen addition increased $\mathrm{CO}_{2}$ and $\mathrm{NO}_{\mathrm{x}}$ and reduced $\mathrm{CO}$ and UHC values compared to unhydrogenated fuels.

- It is observed that higher CR and engine load provided lower $\mathrm{HC}$ and $\mathrm{CO}$ emissions and higher $\mathrm{CO}_{2}$ and $\mathrm{NO}_{\mathrm{x}}$ emissions were emitted.

\section{List of Abbreviations and Nomenclature}

\begin{tabular}{|c|c|}
\hline BTDC & : Before top dead center \\
\hline $\mathrm{CNG}$ & : Compressed natural gas \\
\hline $\mathrm{CO}$ & : Carbon monoxide emissions (ppm/kW) \\
\hline $\mathrm{CO}_{2}$ & : Carbon dioxide emissions (ppm / kW) \\
\hline $\mathrm{CR}$ & : Compression ratio \\
\hline $\mathrm{H}$ & : Hydrogen \\
\hline H 0 & : No hydrogen addition \\
\hline H 2 & : $21 /$ min hydrogen addition \\
\hline H 4 & : 4 1/min hydrogen addition \\
\hline 1 & : Liter \\
\hline MBT & : Maximum brake torque \\
\hline $\min$ & : Minute \\
\hline $\mathrm{n}$ & : Engine speed (RPM) \\
\hline $\mathrm{NO}_{\mathrm{x}}$ & : Nitrogen oxides emissions (ppm / kW) \\
\hline PPM & : Particulate per million \\
\hline SI & : Spark ignition \\
\hline SP & : Spark plug \\
\hline SPG & : Spark plug gap \\
\hline $\mathrm{UHC}$ & $\begin{array}{l}\text { : Total - unburned hydrocarbon } \\
\text { emissions }(\mathrm{ppm} / \mathrm{kW})\end{array}$ \\
\hline VCR & : Variable compression ratio \\
\hline
\end{tabular}

\section{References}

1. S. Yousufuddin, "Experimental study on combustion duration and performance characteristics of a hydrogen-ethanol dual fueled engine", International Journal of Automotive Engineering and Technologies, 5 (3), 85-101, 2016.

2. O. Baş et al., "Effect of Spark Plug Alteration on Performance Using Hydrogen Enriched Gasoline in Si Engine Under Various Loads and Compression Ratios", European Mechanical Science, 2 (3), 92-95, 2018.

3. C. Brand, "Beyond 'Dieselgate': Implications of unaccounted and future air pollutant emissions and energy use for cars in the United Kingdom", Energy Policy, 97, 1-12,
2016.

4. ACEA, "Share of Diesel in New Passenger Cars - 2017", European Automobile Manufacturers Assocation, 2017.

5. M.K. Balki et al., "Experimental Study and Prediction of Performance and Emission in an SI Engine Using Alternative Fuel with Artificial Neural Network", International Journal of Automotive Engineering and Technologies, 7 (1), 58-64, 2018.

6. H. Özcan and A. Çakmak, "Comparative Exergy Analysis of Fuel Additives Containing Oxygen and $\mathrm{HC}$ based in a Spark-Ignition (SI) engine", International Journal of Automotive Engineering and Technologies, 7 (3), 124-133, 2018.

7. A.A. Yontar, "Numerical Comparative Mapping Study to Evaluate Performance of a Dual Sequential Spark Ignition Engine Fuelled with Ethanol and E85", International Journal of Automotive Engineering and Technologies, 7 (3), 98-106, 2018.

8. E. Arabac1, "Thermodynamic analysis of endoreversible six-stroke Otto cycle with respect to equivalence ratio, residual gas fraction and mean piston speed", International Journal of Automotive Engineering and Technologies, 8 (1), 1-10, 2019.

9. O.H. Ghazal, "Performance and combustion characteristic of CI engine fueled with hydrogen enriched diesel", International Journal of Hydrogen Energy, 38 (35), 1546915476, 2013.

10. B. Zhang et al., "Combustion and emissions characteristics of a spark-ignition engine fueled with hydrogen-methanol blends under lean and various loads conditions", Energy, 74, 829-835, 2014.

11. M. Kaplan, "Influence of swirl, tumble and squish flows on combustion characteristics and emissions in internal combustion enginereview", International Journal of Automotive Engineering and Technologies, 8 (2), 83-102, 2019.

12. D. Jung, K. Sasaki, and N. Iida, "Effects of increased spark discharge energy and enhanced in-cylinder turbulence level on lean limits and cycle-to-cycle variations of combustion for SI engine operation", Applied Energy, 205, 1467-1477, 2017.

13. Y. Karagöz et al., "Effect of hydrogen addition on exhaust emissions and performance 
of a spark ignition engine", Environmental Engineering and Management Journal, 14 (3), 665-672, 2015.

14. C. Ji et al., "Effect of hydrogen addition on combustion and emissions performance of a gasoline rotary engine at part load and stoichiometric conditions", Energy Conversion and Management, 121, 272-280, 2016.

15. F. Amrouche et al., "An experimental investigation of hydrogen-enriched gasoline in a Wankel rotary engine", International Journal of Hydrogen Energy, 39 (16), 8525-8534, 2014.

16. O.O. Taskiran, "Fuel-air mixing process of low pressure direct injection in a side ported rotary engine", International Journal of Automotive Engineering and Technologies, 8 (4), 186-194, 2019.

17. B.A. Ceper, "Experimental investigation of the effect of spark plug gap on a hydrogen fueled SI engine", International Journal of Hydrogen Energy, 37 (22), 17310-17320, 2012. 18. H.T. Lin et al., "Characterization of erosion and failure processes of spark plugs after field service in natural gas engines", Wear, 259 (7-12), 1063-1067, 2005.

19. S. Javan, S.V. Hosseini, and A.S. Sh, "An experimental investigation of spark plug temperature in bi-fuel engine and its effect on electrode erosion", International Journal of Automotive Engineering, 2 (1), 21-29, 2012.

20. A. Ortiz et al., "Spark plug failure due to a combination of strong magnetic fields and undesirable fuel additives", Case Studies in Engineering Failure Analysis, 1 (2), 67-71, 2013.

21. F.A. Soldera et al., "Description of the discharge process in spark plugs and its correlation with the electrode erosion patterns", IEEE Transactions on Vehicular Technology, 53 (4), 1257-1265, 2004.

22. N. Pavel et al., "Laser ignition - Spark plug development and application in reciprocating engines", Progress in Quantum Electronics, 58, 1-32, 2018.

23. C. Poggiani et al., "Experimental Characterization of a Multiple Spark Ignition System", Energy Procedia, 82, 89-95, 2015.

24. T.I. No, "All About Spark Plugs", Beru, (02), 2005.

25. F. Amrouche et al., "Extending the lean operation limit of a gasoline Wankel rotary engine using hydrogen enrichment",
International Journal of Hydrogen Energy, 41 (32), 14261-14271, 2016.

26. B. Kurşun and K. Ökten, "Thermodynamic analysis of a Rankine cycle coupled with a concentrated photovoltaic thermal system for hydrogen production by a proton exchange membrane electrolyzer plant", International Journal of Hydrogen Energy, 44 (41), 22863-22875, 2019.

27. P. Dimitriou and T. Tsujimura, "A review of hydrogen as a compression ignition engine fuel", International Journal of Hydrogen Energy, 42 (38), 24470-24486, 2017.

28. Y. Sun, X. Yu, and L. Jiang, "Effects of direct hydrogen injection on particle number emissions from a lean burn gasoline engine", International Journal of Hydrogen Energy, 41 (41), 18631-18640, 2016.

29. T. $\mathrm{Su}$ et al., "Investigation on performance of a hydrogen-gasoline rotary engine at part load and lean conditions", Applied Energy, 205, 683-691, 2017.

30. B. Zhang, C. Ji, and S. Wang, "Performance of a hydrogen-enriched ethanol engine at unthrottled and lean conditions", Energy Conversion and Management, 114, 6874, 2016.

31. X. Zhen et al., "Study of knock in a high compression ratio spark-ignition methanol engine by multi-dimensional simulation", Energy, 50, 150-159, 2013.

32. H. Serin and Ş. Yildizhan, "Influence of the compression ratio on the performance and emission characteristics of a ver diesel engine fuelled with alcohol blended fuels", European Mechanical Science, 1 (2), 39-46, 2017.

33. R. Thomas et al., "Experimental evaluation of the effect of compression ratio on performance and emission of SI engine fuelled with gasoline and n-butanol blend at different loads", Perspectives in Science, 8, 743-746, 2016.

34. Ş. Yildizhan et al., "Fuel properties, performance and emission characterization of waste cooking oil (WCO) in a variable compression ratio (VCR) diesel engine", European Mechanical Science, 1 (2), 56-62, 2017.

35. B.L. Salvi and K.A. Subramanian, "Experimental investigation on effects of compression ratio and exhaust gas recirculation on backfire, performance and emission 
characteristics in a hydrogen fuelled spark ignition engine", International Journal of Hydrogen Energy, 41 (13), 5842-5855, 2016.

36. İ. Altın, A. Bilgin, and B.A. Çeper, "Parametric study on some combustion characteristics in a natural gas fueled dual plug SI engine", Energy, 139, 1237-1242, 2017.

37. S. Yamaguchi et al., "Dual-Point Laser Ignition and its Location Effects on Combustion in Lean-Burn Gas Engine", SAE International Journal of Engines, 2015.

38. C. Ji et al., "Effect of dual-spark plug arrangements on ignition and combustion processes of a gasoline rotary engine with hydrogen direct-injection enrichment", Energy Conversion and Management, 181, 372-381, 2019.

39. S.P.M. Bane, J.L. Ziegler, and J.E. Shepherd, "Investigation of the effect of electrode geometry on spark ignition", Combustion and Flame, 162 (2), 462-469, 2015. 40. İ. Altın and A. Bilgin, "A parametric study on the performance parameters of a twinspark SI engine", Energy Conversion and Management, 50 (8), 1902-1907, 2009.

41. D. Jung and N. Iida, "An investigation of multiple spark discharge using multi-coil ignition system for improving thermal efficiency of lean SI engine operation", Applied Energy, 212, 322-332, 2018.

42. J.D. Dale, M.D. Checkel, and P.R. Smy, "Application of high energy ignition systems to engines", Progress in Energy and Combustion Science, 23 (5-6), 379-398, 1997.

43. İ. Sezer, "A Review Study on the Using of Diethyl Ether in Diesel Engines: Effects on NOx Emissions", International Journal of Automotive Engineering and Technologies, 7 (4), 164-183, 2018. 